GRASAS Y ACEITES 66 (3)

July-September 2015, e089

ISSN-L: 0017-3495

doi: http://dx.doi.org/10.3989/gya.0714142

\title{
A fat quality index (FQI) proposal
}

\author{
J.A. Cobos-Murcia ${ }^{\mathrm{a}, \mathrm{b}}$, A. Osorio-Mirón ${ }^{\mathrm{a}}$, E. Márquez-López ${ }^{\mathrm{a}}$, and E. Hernández-Aguilar ${ }^{\mathrm{a}, \bowtie}$ \\ ${ }^{a}$ Facultad de Ciencias Químicas, Universidad Veracruzana, Ote 6 \# 1009, Orizaba, Veracruz, México. \\ ${ }^{\mathrm{b}}$ Consejo Nacional de Ciencia y Tecnología (Conacyt), Departamento de Cátedras, Av. Insurgentes \\ Sur 1582, Col. Crédito Constructor, Deleg. Benito Juárez, México D.F., C.P. 03940, México \\ Corresponding author: eduhernandez@uv.mx; edward317@hotmail.com
}

Submitted: 10 July 2014; Accepted: 23 February 2015

SUMMARY: This paper presents the concept of the fat quality index (FQI), which is based and established in pursuancet of the current food regulations. It is a numerical value representing the correlated information of all parameters that provide the definition of fat according to the international guidelines. With the implementation of this index, it is possible to compare different types of fats using a single numerical value, which facilitates the elucidation of the effects of treatment processes or origins of fats. The FQI includes all the parameters considered in the regulations by incorporating a sub-index for each parameter and using the minimum and maximum limit values to model and adjust an equation describing the quality of fat according to the standard. Finally, the procedure is used to obtain indices based on other experimental works that assessed the quality of fat samples produced under different operating conditions, treatment, origin or processes, allowing for better comparison and evaluation. Therefore, this index is an excellent analytical tool for assessing the quality of fats from different origins for human consumption.

KEYWORDS: Butter; Fat Quality Index; FQI; Margarine; Standard regulations; Vegetable

RESUMEN: Propuesta de un índice de calidad de grasas (ICG). En este artículo se presenta el concepto de índice de calidad de una grasa (ICG), que se basa y se establece en virtud de los reglamentos alimentarios actuales. Es un valor numérico que representa la información correlacionada de todos los parámetros que proporcionan la definición de la grasa de acuerdo con las directrices internacionales. Con la implementación de este índice es posible comparar los diferentes tipos de grasas usando un único valor numérico, lo que facilita la elucidación de los efectos de los procesos de tratamiento u orígenes de las grasas. El ICG incluye todos los parámetros considerados en la normativa mediante la incorporación de un sub-índice para cada parámetro y utilizando el valor límite máximo y mínimo para componer y ajustar una ecuación que describe la calidad de la grasa de acuerdo con la norma. Por último, el procedimiento se utiliza para obtener los índices en base a otros trabajos experimentales que evaluaron la calidad de las muestras de las grasas producidas bajo diferentes condiciones operacionales, tratamientos, orígenes o procesos, permitiendo una mejor comparación y evaluación. Por lo tanto, este índice es una herramienta analítica excelente para evaluar la calidad de las grasas de diferentes orígenes para el consumo humano.

PALABRAS CLAVE: ICG; Índice de calidad de grasas; Mantequilla; Margarina; Normativa; Vegetales

Citation/Cómo citar este artículo: Cobos-Murcia JA, Osorio-Mirón A, Márquez-López E, Hernández-Aguilar E. A fat quality index (FQI) proposal. 2015. Grasas Aceites 66 (3): e089. doi: http://dx.doi.org/10.3989/gya.0714142.

Copyright: (C) 2015 CSIC. This is an open-access article distributed under the terms of the Creative Commons Attribution-Non Commercial (by-nc) Spain 3.0 Licence. 


\section{INTRODUCTION}

Fats for human consumption have a complex composition that includes sterols, triglycerides, phospholipids, and other components that depend on the type, source, region, or processes to which they may be subjected. However, the quality parameters established in the applicable regulations are numerous, which is problematic during the comparison, analysis of results, and monitoring of processes related to the production and study of fats.

Therefore, to facilitate the interpretation of the obtained results and make them comparable, the fat quality index (FQI) has been established. It has been established in a similar manner to the water quality index (WQI) applied in Mexico (Flores-Jacinto et al., 2013) and in Latin America (Samboni-Ruiz et al., 2007) and internationally (Van Helmond et al., 1997) which employs a weighing system that assigns a weight to each of the parameters under evaluation in the water being studied, establishing the quality conditions displayed. As no quality index for fats or oils has been reported in the literature, nor is one found in the current food regulations, this study takes the creation of such an index into consideration.

The proposed FQI integrates, via a mathematical expression, the values of different parameters and allows the use of a verbal or numeric expression or a color scale to establish the specifications and applicable uses of a specific fat under analysis: pharmaceutical applications, human consumption (Diario Oficial de la Federación, 1999), and raw material for the production of biofuels or disposal (Hee-Yong et al., 2012; Kulkarni and Dalahi, 2006).

To design the FQI, the steps outlined for the development of the WQI are followed. Initially, the selection of the parameters is established, which is performed according to the Delphi and Denius methodology based on criteria established by regulations and scholarly consensus, as well as any criteria relevant to the definition of quality. Therefore, in the case of fats, the parameters used are those established by both the current regulations in force in Latin America and the Codex Alimentarius, as well as by regulations that, although not in force, contain and provide information on different regions to the FQI, as the regulations establish quality criteria and the minimum or maximum allowed values of fats for human consumption whether they are of animal, plant, or mixed origin.

Once the selection of variables is complete, the sub-index of each parameter must be established to transform the value of the dimensional parameter into a dimensionless value and homogenize each value for subsequent combination with the other sub-indices that make up the FQI.

To determine the sub-indices of each parameter, the method of curves was used, based on mathematical models in which the boundary conditions are set according to the regulations (Samboni-Ruiz et al., 2007). This method is considered the most objective and is the most widely accepted. Finally, the ratios and weighted averages for each sub-index are added to determine the FQI (Fernández et al., 2004).

\section{MATERIALS AND METHODS}

The selection of the parameters that determine the FQI depends on the intended use of the fat being evaluated; the most important concern is meeting the requirements for the use of fats for human consumption, either in pharmaceuticals or as food. Based on this criterion, the parameters required by the regulations for lard, cocoa butter, palm oil, butter, and margarine were analyzed.

It is known that the applicable regulations were drafted with the participation of several experts, companies, and institutions from each country. This panel of experts pooled their experience and knowledge from different countries and incorporated the idiosyncrasies of each country and region in Latin America.

\subsection{Fat quality index scale}

The fat quality index scale ranges from 0 to 100 , and represents the quality of the fat as a food product. Five intervals of fat quality are identified: 91 to 100 is classified as excellent, 71 to 90 is considered good, average quality ranges from 51 to 70 , poor quality is from 26 to 50 , and very poor quality ranges between 0 and 25.

The quality index value is determined by the sum of the product of the sub-indices and the weight that is set for each parameter.

\subsection{Determination of the index by aggregation of the sub-indices}

To determine the value of the Fat Quality Index, an equation incorporating the weighed arithmetic average of each parameter was used:

$$
F Q I=\sum_{i=0}^{n} w_{i} S u b_{i}
$$

Where $S u b_{i}$ corresponds to the value of the subindex of the parameter $i$, and $w$ is the weight assigned to each parameter $i$, whose value depends on the importance of each parameter relative to the quality of the fat.

\subsection{Selection and weighting of the parameters}

In the construction of the FQI, only those parameters intrinsic to fats were considered, without considering additive compounds such as colors or antioxidants, which are added during the 
TABLE 1. Fat quality parameters set by the regulations

\begin{tabular}{|c|c|c|c|c|c|c|c|c|}
\hline \multirow{2}{*}{\multicolumn{2}{|c|}{ Parameter }} & \multirow[b]{2}{*}{ Symbol } & \multirow[b]{2}{*}{ Weight } & \multicolumn{4}{|c|}{ Fat } & \multirow[b]{2}{*}{ Regulation applied } \\
\hline & & & & B & $\mathbf{C F}$ & VL & $\mathbf{L}$ & \\
\hline \multicolumn{2}{|l|}{ Humidity $\%$} & $\mathrm{H}$ & 4 & $\mathrm{~A}$ & $\mathrm{~A}$ & A & $\mathrm{A}$ & $1,2,3,4,5,6,11,14,15,18,21,22,23,25,26$ \\
\hline \multicolumn{2}{|l|}{ Melting point } & MP & 4 & A & A & A & A & $1,5,9,14,15,17,18,21,22,23,24,25,26$ \\
\hline \multicolumn{2}{|c|}{ Solidification point of fatty acids in ${ }^{\circ} \mathrm{C}$} & SP & 4 & NA & NA & NA & A & 18 \\
\hline \multicolumn{2}{|c|}{ Specific gravity of $40 / 25^{\circ} \mathrm{C}$} & $\rho$ & 4 & NA & NA & A & A & $17,18,20$ \\
\hline \multicolumn{2}{|c|}{ Refractive Index $313 \mathrm{~K}\left(40{ }^{\circ} \mathrm{C}\right)$} & $\eta$ & 4 & A & NA & A & A & $1,2,3,16,17,18,19,20,22$ \\
\hline \multicolumn{2}{|c|}{ Saponification Index } & Sap & 5 & A & NA & A & A & $1,2,3,14,1,5,16,17,18,20,21,22$ \\
\hline \multicolumn{2}{|c|}{ Unsaponifiable materials ( $\mathrm{g} / \mathrm{kg}$ fat) } & USap & 4 & NA & NA & NA & A & $14,18,20,21,23,24,25$ \\
\hline \multicolumn{2}{|c|}{ Iodine Index (Hanus) } & I & 5 & A & NA & NA & A & $1,2,3,17,18,19,20,21,22$ \\
\hline \multicolumn{2}{|c|}{ Acidity expressed in lactic acid $\%(\mathrm{~m} / \mathrm{m})$} & A & & A & NA & NA & NA & 3 \\
\hline \multicolumn{2}{|c|}{ Free acidity $(\%)$ as lauric acid $\%$} & A & 4 & NA & NA & NA & A & 17,18 \\
\hline \multicolumn{2}{|c|}{ Free acidity $(\%)$ as oleic acid } & A & & NA & A & A & A & $8,11,14,15,16,18,23,24,25$ \\
\hline \multicolumn{2}{|c|}{ Peroxide Index (meq. of $\mathrm{O}_{2} \cdot \mathrm{kg}^{-1}$ fat) } & $\mathrm{P}$ & 5 & A & A & NA & A & $4,10,14,18,21,23$ \\
\hline \multicolumn{2}{|l|}{ Fat $\%(\mathrm{~m} / \mathrm{m})$} & $\mathrm{F}$ & 5 & A & A & NA & NA & $2,3,4,5,7,11,24$ \\
\hline \multicolumn{2}{|c|}{ Reichert- Meisst index } & $\mathrm{Re}$ & & A & NA & NA & NA & 1,2 \\
\hline \multicolumn{2}{|l|}{ Polenske Index } & Po & 4 & A & NA & NA & NA & 1,2 \\
\hline \multicolumn{2}{|l|}{ Kirchner index } & $\mathrm{Ki}$ & & A & NA & NA & NA & 1 \\
\hline \multicolumn{2}{|l|}{ Böemer Index } & Bo & 4 & NA & NA & NA & A & 18 \\
\hline \multicolumn{2}{|l|}{ Suspended solids } & Ss & 4 & NA & NA & NA & A & 18,19 \\
\hline \multicolumn{2}{|l|}{ Rancidity } & $\mathrm{R}$ & 5 & NA & NA & NA & A & 18 \\
\hline \multicolumn{2}{|l|}{ Sodium soap } & sso & 4 & NA & NA & NA & A & 20 \\
\hline \multicolumn{2}{|c|}{ Unsolvable material } & $\mathrm{UM}$ & 4 & NA & NA & NA & A & $16,18,19,23,24$ \\
\hline Iron & & $\mathrm{Fe}$ & & NA & $\mathrm{A}$ & $\mathrm{A}$ & $\mathrm{A}$ & $6,16,19,20,23,24,26,27$ \\
\hline Copper & & $\mathrm{Cu}$ & 5 & NA & A & A & A & $5,16,20,23,24,26,27,28$ \\
\hline Plumbum & & $\mathrm{Pb}$ & & NA & A & A & A & $5,16,19,20,23,26,29$ \\
\hline Arsenic & & As & & NA & A & A & A & $5,16,19,20,23,24,26,28,29,30$ \\
\hline Nickel & & $\mathrm{Ni}$ & & NA & A & NA & A & $5,19,23,24,25,28,29$ \\
\hline Yellow & & $\mathrm{Y}$ & & A & A & A & A & $1,15,19,20,24,25$ \\
\hline Red & & $\mathrm{R}$ & 4 & NA & A & NA & A & $18,19,23,25$, \\
\hline Blue & & $\mathrm{B}$ & & NA & A & NA & A & $18,23,25$ \\
\hline Unsaturated/sat & rated & $\frac{\text { Insat }}{\text { Sat }}$ & 5 & NA & NA & NA & A & $18,19,31$ \\
\hline Smell and taste & & $\mathrm{ST}$ & 5 & NA & A & A & A & $5,13,16,18,19,20,24,28,31,31$ \\
\hline Texture & & $\mathrm{T}$ & 4 & NA & A & A & A & $5,14,18,19,24,31$ \\
\hline Appearance & & A & 4 & NA & A & A & A & $1,5,14,19,24,31$ \\
\hline Fat & Butter (B), Composed & and hydro & genated & fat $(\mathrm{C}$ & F), ve & getabl & e lard & VL) and Lard (L) \\
\hline Regulations & $\begin{array}{l}\text { 1) NMX-F-010, 1982; } \\
\text { 1993; 5) NMX-F-016 } \\
\text { COVENIN 325, } 2001 \\
\text { 1981; 13) NCh1606, } \\
\text { COVENIN 2192, 200 } \\
\text { 211, 1999; 21) COVEI } \\
\text { 25) NCh118.Of66, 19 } \\
\text { 2001; 29) NCh117 Of }\end{array}$ & $\begin{array}{l}\text { 2) NTE II } \\
\text { SCFI-2007 } \\
\text { 9) COVEI } \\
80 ; 14) \mathrm{N} \\
\text {; 18) NM } \\
\text { JIN } 3369 \text {, } \\
6 ; 26) \mathrm{CO} \\
9,1969 ; 3(\end{array}$ & $\begin{array}{l}\text { NEN } 161 \\
\text {, 2007; } 6 \\
\text { NIN } 172 \\
\text { MX-F-3 } \\
\text { X-F-110- } \\
\text { 1998; 22 } \\
\text { DEX ST } \\
\text { 0) RTCA }\end{array}$ & $\begin{array}{l}2011 \\
\text { COV } \\
7,199 \\
73-S C \\
1999, \\
\text { NCh } \\
\text { AN } 32 \\
67.04\end{array}$ & $\begin{array}{l}\text { 3) C } \\
\text { ENII } \\
6,10) \\
1,20 \\
19) \mathrm{N} \\
14 . \mathrm{O} \\
198 \\
40: 07\end{array}$ & $\begin{array}{l}\text { OVEN } \\
\text { N } 704- \\
\text { COVE } \\
05 ; 15 \\
\text { Ormas } \\
\text { f58, } 1 \\
; 27) \\
2007\end{array}$ & $\begin{array}{l}\text { NIN } 12 \\
705-7 \\
\text { ENIN } \\
\text { NCl } \\
\text { Arge } \\
958 ; 2 \\
\text { CODI } \\
7 \text {;1) }\end{array}$ & $\begin{array}{l}\text { 0,1994; 4) MERCOSUR/GMC/RES. No 70/93, } \\
\text { 6-708, 1995; 7) COVENIN 1726, 1997; 8) } \\
\text { 508, 1997; 11) NCh 1654, 1979; 12) NCh95, } \\
\text { 116, 1958; 16) CODEX-STAN-086-1981; 17) } \\
\text { tinas Artículo 541, 2012; 20) CODEX STAN } \\
\text { ) NTC 198, 2013; 24) NTE INEN 1313, 2012; } \\
\text { X STAN 19, 1981; 28) COVENIN 70:2001, } \\
\text { JMX-F-165-SCFI, 2007 }\end{array}$ \\
\hline
\end{tabular}

formulation and packaging processes and, therefore, cannot be considered main components of the fats.

Table 1 shows the parameters considered in this analysis, where the specifications found in all the consulted regulations are established. Likewise, the abbreviations used in this work and the weights assigned to each parameter are shown. It should be noted that certain parameters are considered indicators of purity and are reported in the regulations to establish the quality of a fat or oil based 
on measurement of the amount of diluting agents in its composition.

\subsubsection{Physicochemical parameters}

This study considered the physicochemical parameters present in all regulations and omitted parameters that only apply specifically to margarine and butter, such as $\mathrm{pH}$, phosphatase, stability, and dry matter content, which are not considered in the proposed index because they only found in the regulations for a single type of fat. Among these parameters can be found non-fat solids, phosphatase, linoleic acid, casein, fat acidity, conservatives, and sodium chloride type I and II.

\subsubsection{Fatty acid profile and ratio of unsaturated/saturated fatty acids}

Fatty acid composition is complex, and the regulations consider over 15 parameters. The fatty acid profile has great importance in the quality of a fat. However, including these parameters in addition to the physicochemical ones would make the calculation of the FQI too complex and would not properly represent the interests of the fatty acid profile.

The use of the ratio of unsaturated/saturated fatty acids, which is the ratio between the sum of unsaturated fatty acids and the sum of saturated fatty acids expressed as a percentage, is proposed. This definition is a representation of the fatty acid profile that groups all the components together (Valenzuela et al., 2010).

Subindex $_{\text {unsat } / \text { sat }}=\frac{\sum_{14 \geq i \geq 20}^{n} \sum_{j \neq 0}^{n} x_{C i: j}}{\sum_{14 \geq i \geq 20}^{n} \sum_{j=0}^{n} x_{C i: j}}$

The maximum and minimum values of the ratio of unsaturated/saturated fatty acids are not established in the regulations, so to define these values, two limiting cases are set considering the values of each fatty acid.

Thus, to determine the minimum allowed value of the unsaturated/saturated ratio, the sum of the percentages of all unsaturated fatty acids at their minimum allowed value divided by the sum of the percentages of all saturated fatty acids at their maximum allowed value is considered. Thus, the first limiting case is obtained as a ratio that represents a fat sample with the smallest allowed amount of unsaturated fatty acids and the maximum of saturated ones. This value can be represented by the following equation:

Lower Limit Subindex $x_{\text {unsat } \text { sat }}=\frac{\sum_{14 \geq i \geq 20}^{n} \sum_{j \neq 0}^{n} x_{C i: j}^{M i n}}{\sum_{14 \geq i \geq 20}^{n} \sum_{j=0}^{n} x_{C i: j}^{M a x}}$
Likewise, to obtain the maximum allowed value of the unsaturated/saturated ratio, the sum of the percentages of unsaturated fatty acids at their maximum allowed value is divided by the sum of the percentages of all saturated fatty acids at their minimum allowed value. Thus, a sample with a small content of saturated fatty acids and a large content of unsaturated ones is considered:

Upper Limit Subindex unsat $s a t=\frac{\sum_{14 \geq i \geq 20}^{n} \sum_{j \neq 0}^{n} x_{C i: j}^{M a x}}{\sum_{14 \geq i \geq 20}^{n} \sum_{j=0}^{n} x_{C i: j}^{M i n}}$

\subsubsection{Organoleptic parameters}

Finally, the organoleptic characteristics are considered, which are of great importance in the quality of the fat due to its use in foods and can significantly alter the quality of the products.

\subsection{Determination of the sub-index of the parameters}

With the purpose of transforming the variables to a dimensionless scale to then integrate them into the FQI, each type of contribution is determined depending on the characteristics and trends seen in the regulations.

\subsubsection{Nominal parameters}

Organoleptic parameters (except color) and the Kreiss reaction are qualitative determinations. Thus, it is not possible to determine the value of the subindex mathematically, as it only provides nominal values such as negative or positive. Therefore, the use of the value 100 is proposed for those samples that meet the value accepted by the regulations, and a value of three is proposed for samples that do not meet the regulations.

\subsubsection{Statistical analysis of the parameters}

A statistical analysis of the parameters is performed using the computer program Origin Pro 8, evaluating measures of central tendency such as the average, mode, and median, in addition to the dispersion, standard deviation, coefficient of symmetry, kurtosis, and percentiles.

With the analysis and inspection of the statistical results, the most suitable mathematical model is proposed, considering the values of central tendency, kurtosis, and symmetry, in addition to the analysis of the behavior of tens of percentiles. Additionally, the lower and upper confidence limits for $95 \%$ of the population of the analyzed data are determined.

The variability and confidence intervals are determined both statistically, according to the standard deviation, and in accordance with the regulations 
regarding the significant values of each parameter, which are set according to the standard analytical detection method employed. This procedure allows for the use of two significant numbers in the FQI.

Furthermore, the averages were evaluated in chunks corresponding to the main types of fats: animal (e.g., butter fat, butter milk), vegetable (e.g., palm oil, cocoa butter), and mixed (margarine and hydrogenated).

\subsubsection{Parameters described by mathematical models}

Most of the parameters have sub-indices that are obtained by the method of curves described by mathematical equations and based on the regulations. Using these sub-indices, each parameter is described in an objective manner through the correlation between the actual value of the parameter and the $0-100$ sub-index scale of each parameter; this method is the most widely accepted (SamboniRuiz et al., 2007).

The values of the lower and upper confidence limits or ranges of statistical acceptance of the data extracted from the regulations for each parameter are considered to determine the necessary minimum value to be labelled a fat with acceptable quality, which in this case is considered to be a value of 71 .

Furthermore, depending on the type of tendency the parameter shows, the mathematical model chosen is the one that shows the best fit to the expected behavior and to the results of the statistical analysis. To determine the model, the tens of percentiles of the FQI statistical analysis are correlated with the values of 71 and 100 for a fat that meets the quality criteria.

To establish the parameters, linear, exponential, potential, and non-linear mathematical models were used. Adjustments were made using the computer programs Excel and OriginPro 8. Although in most cases it was also possible to describe the behavior using a more complex model, the simplest mathematical model that adequately described the data was preferred.

However, some parameters display more complex tendencies, so it was necessary to consider multiple models that describe multiple parameters with a single index. Thus, the metals and Lovibond parameters are expressed as the algebraic sum of each parameter in an equation with multiple variables. Similarly, the Reichert-Meissl, Polenske, and Kirchner values are integrated into a single parameter that represents volatile fatty acids.

\section{RESULTS}

\subsection{Statistical analysis of the parameters}

In Table 2, the results of the statistical study that was performed considering all quality parameters of fats gathered from the International Guidelines are shown. The average value, standard deviation, skewness, kurtosis, and the lower and upper confidence intervals for $95 \%$ of the population are shown.

By analyzing the measures of central tendency, it is possible to establish the value of each parameter of an average fat. Based on the standard deviation, the data variability is established, which also allows the determination of the values of the lower and upper limits of confidence for $95 \%$ of the population.

Furthermore, the analyses of the dispersion values allow us to analyze the data distribution, in addition to the distribution of percentiles, as seen in Figures 1 to 19, which represents each parameter in one graph. $S u b_{i}$ is considered, depending on the value of the parameter in the corresponding units. The black dots represent percentiles that fit in the $S u b_{i}$ scale between the values of 71 and 100 according to the expected behavior for each parameter. Similarly, the adjustment of the mathematical model is plotted on the dotted line and circles, representing the relationship between each sub-index and the parameter value.

\subsection{Mathematical models of the sub-indices of the FQI parameters}

In Table 3, the mathematical models for each evaluated parameter are shown. Each of them shows the equation that describes the behavior of the regulatory data and the range in which such an equation is valid.

In Table 4, the average values and sub-indices of each parameter are shown for three types of fats according to their origin: animal, vegetable, or mixed. At the end of this table, the fat quality index is found. The value corresponds to an average type of fat, and each parameter was used for the calculation of the sub-index using the appropriate mathematical model. In the case of a parameter that does not appear in any of the regulations, such as the Specific gravity for mixed fat, which is not a parameter within those regulations, the assigned value is the value of the overall average.

Finally, the quality index for each type of fat according to its origin and the overall average shows values above 93, which corresponds to fats of excellent quality within all international guidelines.

\section{DISCUSSION}

\subsection{Application of the Fat Quality Index}

Figure 20 shows the application of the fat quality index to compare results obtained in several experimental works, which determine the effect of the origin or applied processes on the quality. Each set of bars corresponds to a different work, and each bar corresponds to a fat under study reported 
6• J.A. Cobos-Murcia, A. Osorio-Mirón, E. Márquez-López and E. Hernández-Aguilar

TABLE 2. Statistical results of fat regulations data

\begin{tabular}{|c|c|c|c|c|c|c|}
\hline Parameter & Average & Standard deviation & Kurtosis & Skewness & LCI 95\% & UCI 95\% \\
\hline Specific gravity & 0.9157 & 0.033 & 1.60 & 1.1 & 0.8432 & 0.9745 \\
\hline Melting point & 37.7 & 8.0 & -0.15 & 0.026 & 30.5 & 54.6 \\
\hline Solidification point & 38.0 & 6.9 & -0.24 & -2.1 & 29.7 & 50.5 \\
\hline Refractive index & 1.4560 & 0.0051 & 0.057 & -0.52 & 1.4483 & 1.4635 \\
\hline Saponification index & 207.3 & 19.4 & 0.78 & -0.36 & 185.1 & 243.1 \\
\hline Iodine index & 45.62 & 17.5 & 0.074 & -0.92 & 36.1 & 88.5 \\
\hline Unsaponifiable & 10.1 & 5.1 & -0.051 & -0.92 & 5.0 & 20.2 \\
\hline Acidity index & 1.602 & 1.9 & 2.3 & 7.04 & - & 5.1 \\
\hline Humidity & 6.69 & 8.1 & 0.51 & -1.8 & - & 23.9 \\
\hline Peroxide & 5.19 & 3.5 & 0.41 & -1.4 & 13.6 & 13.6 \\
\hline Böemer & 72.3 & 1.2 & -1.7 & - & 75.1 & 75.1 \\
\hline Reichert-meissl & 27.8 & 5.4 & 0.29 & -1.7 & 36.4 & 36.4 \\
\hline Polenske & 2.9 & 1.9 & 0.79 & -0.12 & 6.6 & 6.6 \\
\hline Kirchner & 22.5 & 5.0 & - & - & 32.4 & 32.4 \\
\hline Fat percent & 78.3 & 12.4 & 0.20 & 0.12 & 67 & - \\
\hline Sodium soap & 0.0043 & 0.0010 & -0.97 & & - & 0.0068 \\
\hline Unsolvable material & 0.0463 & 0.011 & -2.8 & 8 & - & 0.07 \\
\hline Iron & 1.5938 & 1.0 & 2.5 & 8.4 & - & 8.3 \\
\hline Copper & 0.1667 & 0.13 & 1.5 & 0.14 & - & 3.6 \\
\hline Plumbum & 0.0946 & 0.019 & -3.6 & 13 & - & 0.38 \\
\hline Arsenic & 0.1 & 0.017 & -4.6 & 5 & - & 0.14 \\
\hline Nickel & 0.3667 & 0.56 & 2.3 & 5.6 & - & 0.1 \\
\hline Yellow & 36 & 13.7 & -1.0 & 1.6 & 22 & 62.6 \\
\hline Blue & 5 & 1.8 & 2.3 & 5.9 & 3 & 8.7 \\
\hline Red & 4 & 4.2 & - & - & 0 & 12.5 \\
\hline Unsaturated/saturated & 3.5 & - & - & - & 0.2827 & 6.3240 \\
\hline
\end{tabular}

within the publication. Notably, there is trust in the compliance of the variability and confidence intervals of the analytical methods of each experimental work according to the acceptance criteria for precision and accuracy of at least 3\% established by all

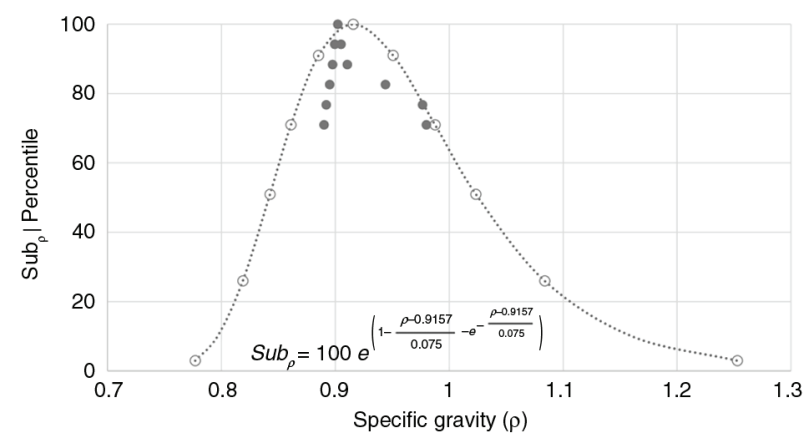

FIGURE 1. Graphs showing the correlation function of specific gravity. Black dots showing percentiles and dotted lines with circle adjustments are proposed equations to describe the parameter. regulatory entities regarding the variability of the analytical methods. Thus, in each work's results, the value of the FQI should be significantly different, coupled with the integration of the different parameters that compose it.

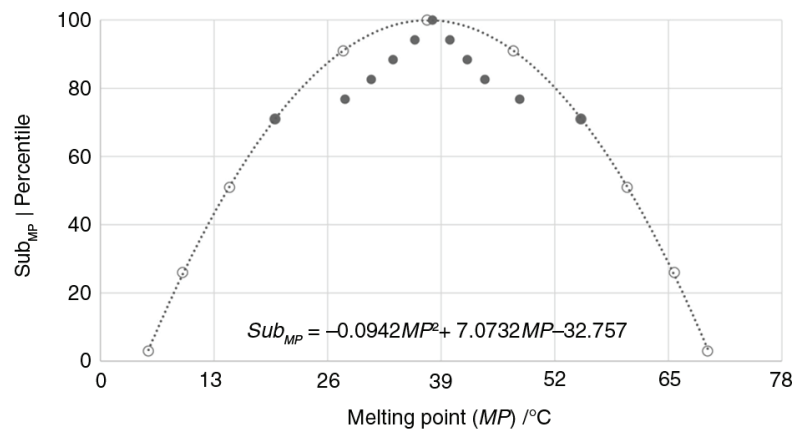

FIGURE 2. Graphs showing the correlation function of melting point. Black dots showing percentiles and dotted lines with circle adjustments are proposed equations to describe the parameter. 


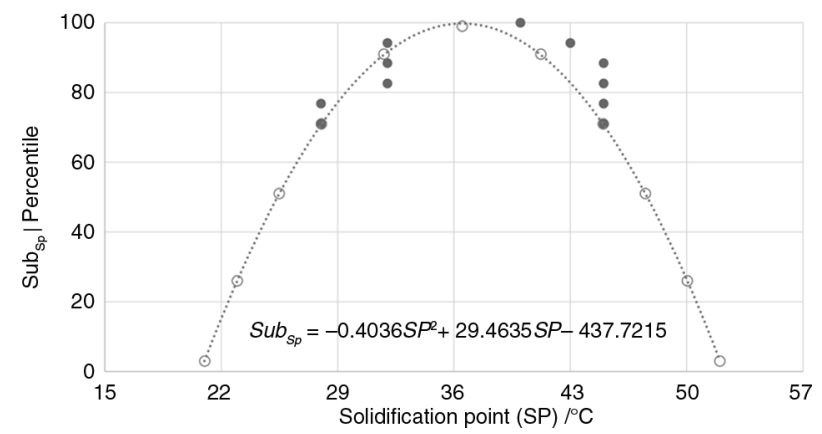

FIGURE 3. Graphs showing the correlation function of solidification point. Black dots showing percentiles and dotted lines with circle adjustments are proposed equations to describe the parameter.

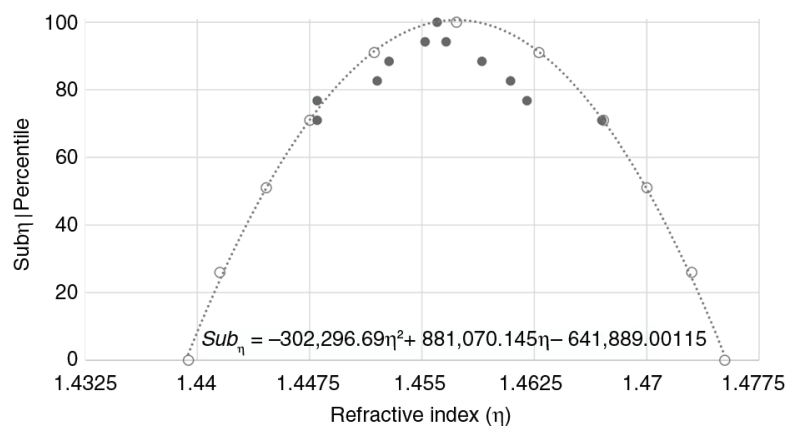

FIGURE 4. Graphs showing the correlation function of refractive index. Black dots showing percentiles and dotted lines with circle adjustments are proposed equations to describe the parameter.

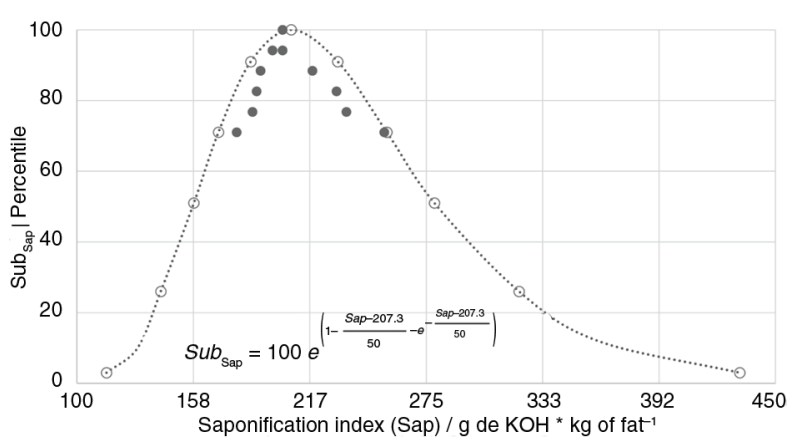

FIGURE 5. Graphs showing the correlation function of saponification index. Black dots showing percentiles and dotted lines with circle adjustments are proposed equations to describe the parameter.

Rose-Monde et al. (2007) studied shea butter of different colors (I). In the first section of his investigation, he determined the characteristics of the fat sold in the Ivory Coast. The discussion in the article presents many parameters to assess its quality;

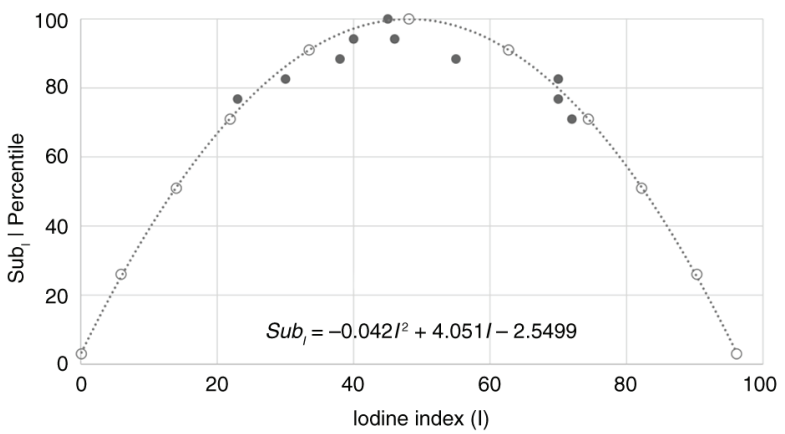

FIGURE 6. Graphs showing the correlation function of iodine index. Black dots showing percentiles and dotted lines with circle adjustments are proposed equations to describe the parameter.

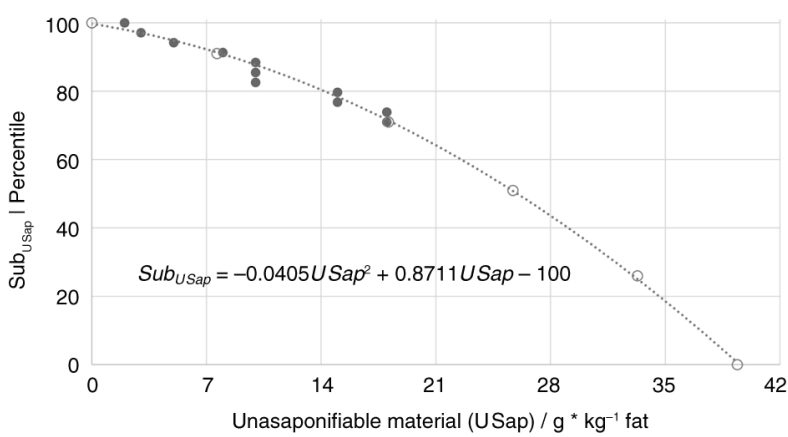

FIGURE 7. Graphs showing the correlation function of unsaponifiable materials. Black dots showing percentiles and dotted lines with circle adjustments are proposed equations to describe the parameter.

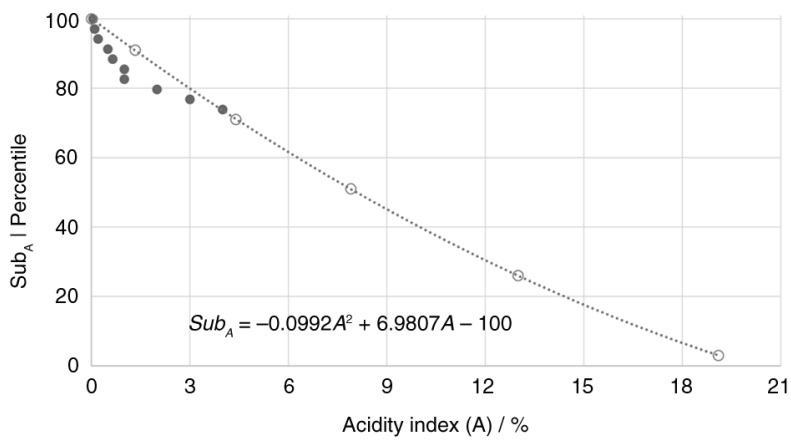

FIGURE 8. Graphs showing the correlation function of acidity index. Black dots showing percentiles and dotted lines with circle adjustments are proposed equations to describe the parameter.

therefore, the discussion is complicated because in addition to not assigning a weight to each of the parameters under study and not grouping the net effects of each parameter, this presentation makes it difficult to establish which fat has the best quality. 


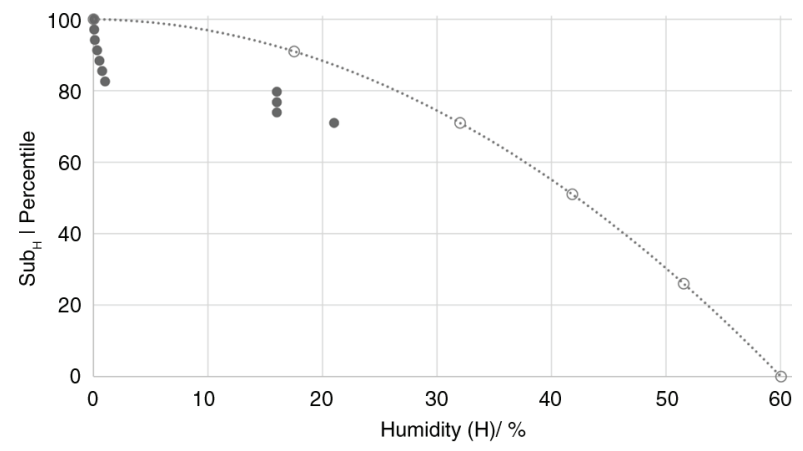

FIGURE 9. Graphs showing the correlation function of humidity. Black dots showing percentiles and dotted lines with circle adjustments are proposed equations to describe the parameter.

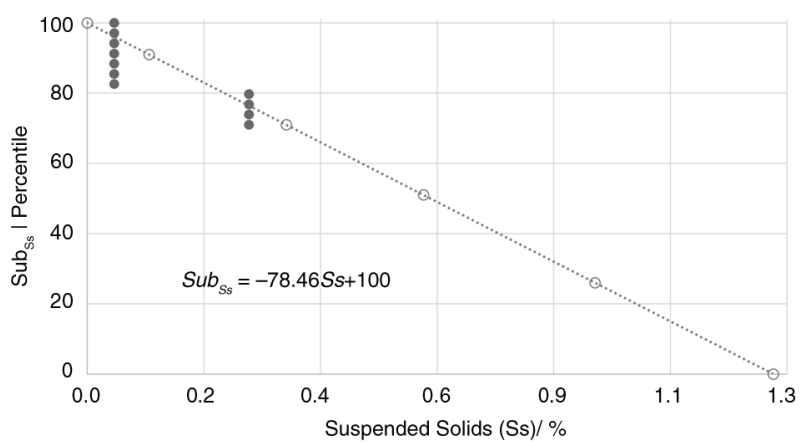

FIGURE 10. Graphs showing the correlation function of suspended solids. Black dots showing percentiles and dotted lines with circle adjustments are proposed equations to describe the parameter.

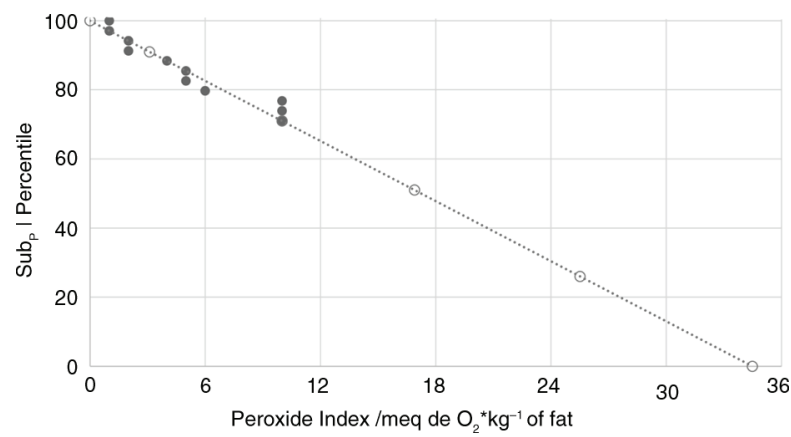

FIGURE 11. Graphs showing the correlation function of peroxide index. Black dots showing percentiles and dotted lines with circle adjustments are proposed equations to describe the parameter.

Thus, applying the FQI model, the obtained values are 84.65 for the fat with a beige color (A), 83.85 for the fat with a yellow color (B), and 86.26 for the fat with a grey color $(\mathrm{C})$, which facilitates choosing the raw material of the highest quality.

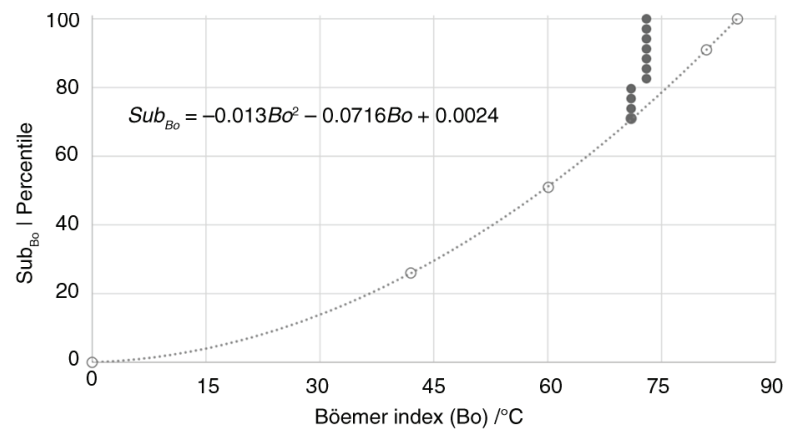

FIGURE 12. Graphs showing the correlation function of Böemer index. Black dots showing percentiles and dotted lines with circle adjustments are proposed equations to describe the parameter.

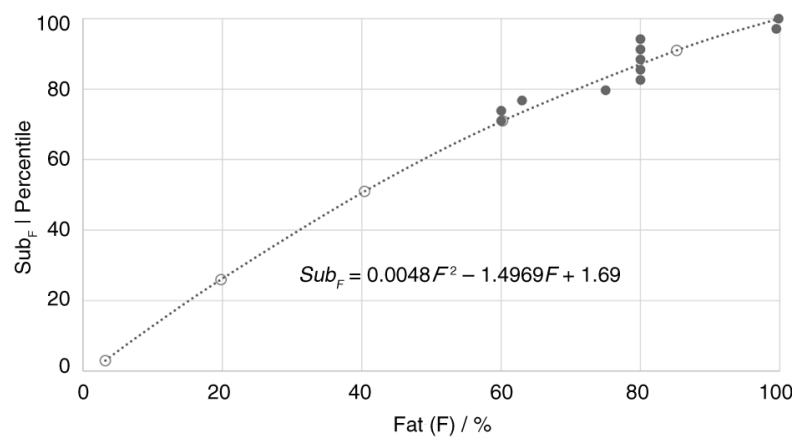

FIGURE 13. Graphs showing the correlation function of fat percent. Black dots showing percentiles and dotted lines with circle adjustments are proposed equations to describe the parameter.

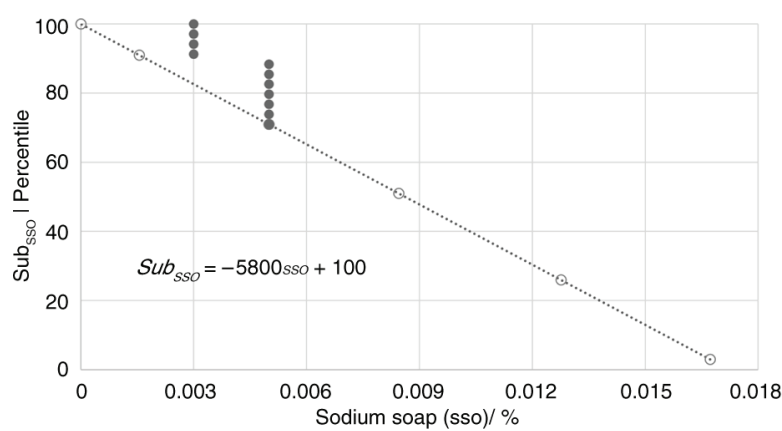

FIGURE 14. Graphs showing the correlation function of sodium soap. Black dots showing percentiles and dotted lines with circle adjustments are proposed equations to describe the parameter.

Yellow shea butter is consumed most frequently and can be processed to improve its physicochemical properties; a comparison of these properties before and after treatment is shown in Figure 2 in the second group of bars (II). An increase in the FQI value 


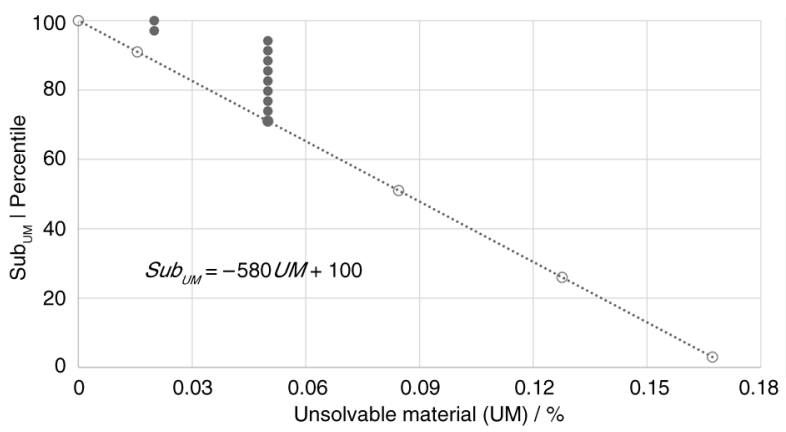

FIGURE 15. Graphs showing the correlation function of unsolvable material. Black dots showing percentiles and dotted lines with circle adjustments are proposed equations to describe the parameter.

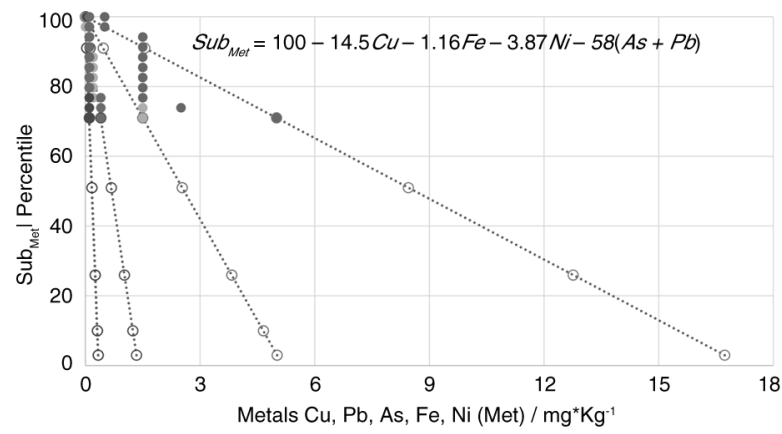

FIGURE 16. Graphs showing the correlation function of metals. Black dots showing percentiles and dotted

lines with circle adjustments are proposed equations to describe the parameter.

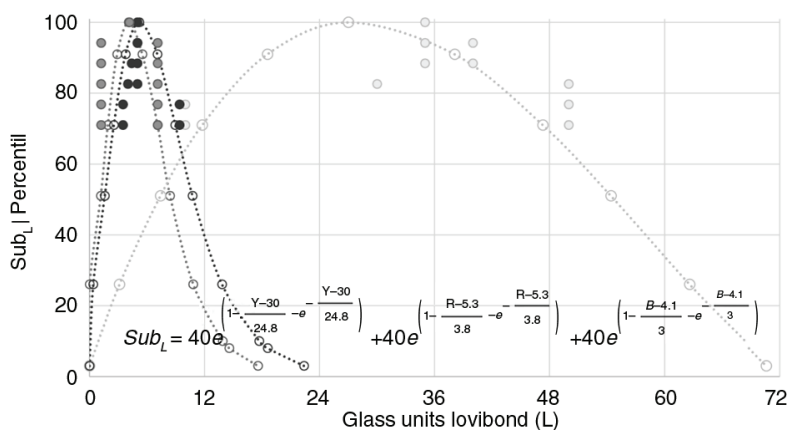

FIGURE 17. Graphs showing the correlation function of parameters comprising the Lovibond color. Black dots showing percentiles and dotted lines with circle adjustments are proposed equations to describe the parameter.

from 83.85 (A) to 86.83 (B) can be observed, along with an improved metal concentration and moisture content, as well as minor changes in parameters such as refractive index and boiling point.

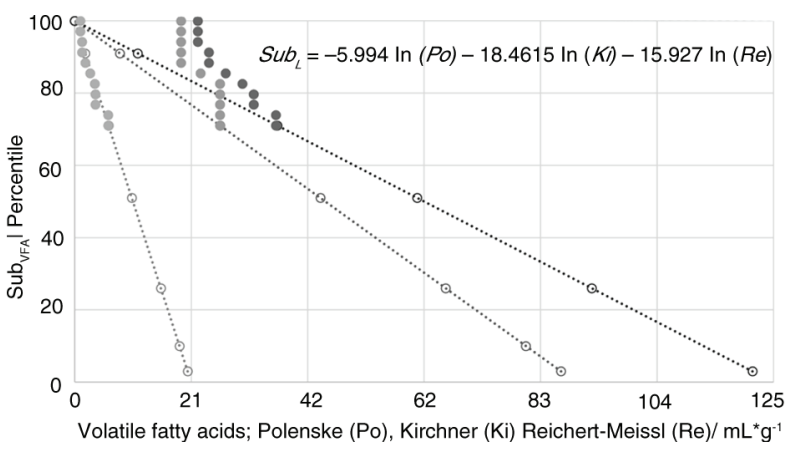

FIGURE 18. Graphs showing the correlation function of the parameters comprising the volatile fatty acids. Black dots showing percentiles and dotted lines with circle adjustments are proposed equations to describe the parameter.

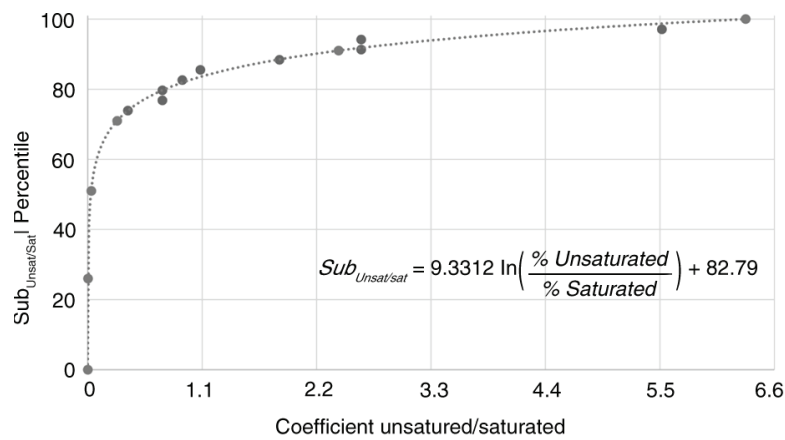

FIGURE 19. Graphs showing the correlation function of the coefficient unsaturated/saturated fatty acids. Black dots showing percentiles and dotted lines with circle adjustments are proposed equations to describe the parameter.

In 2012, Dhurvey studied the effect of hydrogenation on ghee (III), a traditional butter from India that is prepared at home, and he evaluated its hydrogenation (Dhurvey et al., 2012). He observed a variation in the FQI value from 88.14 (A) down to 79.59 (B) before and after the process, respectively, representing a decrease in the quality, which is mainly attributable to the loss of unsaturated fats during the hydrogenation process.

Sağdiç (2004) assessed the butters of 3 different animal origins (IV): goat, sheep, and cow. The work shows mixed results due to the proximity of the results in some parameters and the random behavior of others, which prevented him from determining the superiority of the characteristics of one butter over the others. However, by applying the FQI, the values obtained are $85.81(\mathrm{~A}), 85.85(\mathrm{~B})$, and $87.05(\mathrm{C})$, respectively, which makes it possible to establish that the quality of cow's butter has a higher index and, thus, is of higher quality than the other butters under evaluation.

In 2010, Okullo evaluated shea butter from different regions of Uganda (V), Pader, Lira, Katakwi, 
10 J.A. Cobos-Murcia, A. Osorio-Mirón, E. Márquez-López and E. Hernández-Aguilar

TABLE 3. Statistical values and subindex of the quality parameters of different types of fats and the overall average

\begin{tabular}{|c|c|c|c|c|c|c|c|c|}
\hline \multirow[b]{2}{*}{ Parameter } & \multicolumn{2}{|c|}{ Lard } & \multicolumn{2}{|c|}{ Vegetable lard } & \multicolumn{2}{|c|}{$\begin{array}{c}\text { Composed and } \\
\text { hydrogenated fat }\end{array}$} & \multicolumn{2}{|c|}{ Average } \\
\hline & Value & Sub & Value & Sub & Value & Sub & Value & Sub \\
\hline Specific gravity & 0.9 & 98 & 0.9262 & 99 & 0.9157 & 100 & 0.9157 & 100 \\
\hline Melting point & 37.3 & 100 & 34.6 & 99 & 43.0 & 97 & 37.7 & 100 \\
\hline Solidification point & 37.9 & 99 & 38.5 & 98 & 38.0 & 99 & 38.0 & 99 \\
\hline Refractive index & 1.4553 & 99 & 1.4574 & 100 & 1.4560 & 99 & 1.4560 & 99 \\
\hline Saponification index & 209.68 & 100 & 202.70 & 100 & 207.28 & 100 & 207.28 & 100 \\
\hline Iodine index & 47.83 & 100 & 40.63 & 98 & 45.62 & 100 & 45.62 & 100 \\
\hline Unsaponifiable & 9.25 & 88 & 10.67 & 86 & 13.00 & 82 & 10.25 & 87 \\
\hline Acidity index & 1.289 & 91 & 2.217 & 84 & 0.700 & 95 & 1.602 & 89 \\
\hline Humidity & 6.29 & 99 & 0.23 & 100 & 14.25 & 94 & 6.69 & 99 \\
\hline Suspended Solids & 0.1333 & 90 & 0.1333 & 90 & 0.1333 & 90 & 0.1333 & 90 \\
\hline Rancidity & + & 100 & + & 100 & + & 100 & + & 100 \\
\hline Peroxide & 5.64 & 84 & 5.13 & 85 & 3.00 & 91 & 5.19 & 85 \\
\hline Böemer & 72.3 & 73 & 72.3 & 73 & 72.3 & 73 & 72.3 & 73 \\
\hline Reichert-Meissl & 27.8 & 78 & 27.8 & 78 & 27.8 & 78 & 27.8 & 78 \\
\hline Polenske & 2.9 & 86 & 2.9 & 86 & 2.9 & 86 & 2.9 & 86 \\
\hline Kirchner & 22.5 & 75 & 22.5 & 75 & 22.5 & 75 & 22.5 & 75 \\
\hline Volatile fatty acids & & 79 & & 79 & & 79 & & 79 \\
\hline Fat percent & 83.2 & 90 & 74.0 & 83 & 74.0 & 83 & 78.3 & 86 \\
\hline Sodium soap & 0.0050 & 71 & 0.0037 & 79 & 0.0043 & 75 & 0.0043 & 75 \\
\hline Unsolvable material & 0.0500 & 71 & 0.0425 & 75 & 0.0463 & 73 & 0.0463 & 73 \\
\hline Iron & 1.3750 & 92 & 2.6250 & 85 & 1.0000 & 94 & 1.5938 & 91 \\
\hline Copper & 0.19 & 86 & 0.1750 & 87 & 0.1 & 93 & 0.1667 & 88 \\
\hline Lead & 0.1 & 71 & 0.1000 & 71 & 0.0860 & 75 & 0.0946 & 73 \\
\hline Arsenic & 0.1 & 71 & 0.1000 & 71 & 0.1 & 71 & 0.1 & 71 \\
\hline Nickel & 0.1 & 98 & 0.6333 & 88 & 0.6333 & 88 & 0.3667 & 93 \\
\hline Metals & & 79 & & 77 & & 80 & & 79 \\
\hline Yellow & 27 & 100 & 43 & 83 & 36 & 95 & 36 & 95 \\
\hline Blue & 6 & 81 & 5 & 99 & 5 & 95 & 5 & 95 \\
\hline Red & 4 & 95 & 6 & 98 & 4 & 95 & 4 & 95 \\
\hline Lovibond & & 94 & & 92 & & 95 & & 95 \\
\hline Unsaturated/saturated & 1.7 & 88 & 6.0 & 100 & 3.5 & 95 & 3.5 & 95 \\
\hline Smell and taste & + & 100 & + & 100 & + & 100 & + & 100 \\
\hline Texture & + & 100 & + & 100 & + & 100 & + & 100 \\
\hline Appearance & + & 100 & + & 100 & + & 100 & + & 100 \\
\hline FQI & \multicolumn{2}{|c|}{93.05} & \multicolumn{2}{|c|}{93.28} & \multicolumn{2}{|c|}{93.61} & \multicolumn{2}{|c|}{93.51} \\
\hline
\end{tabular}

and Arua, and he showed the variation in the quality parameters in each of these regions (Okullo et al., 2010); as it is the same product and the samples were collected in the same geographic proximity, discussion of the results of the different parameters is difficult. Applying the FQI, values of 89.86 (A), 90.31 (B), 89.09 (C), and 87.13 (D) are obtained, respectively. This result shows that the shea butter with the best quality is from Lira, followed by the shea butter from Pader, Katakwi, and finally Urua.

To use the proposed quality index, the FQI calculator developed in MS EXCEL is made available at the following address: https://t.co/AZDRIBFouO, where the minimum and maximum accepted values are shown in addition to the optimal value; this calculator allows the calculation of the FQI by entering the values of a sample that has been analyzed. 
TABLE 4. Parameter's subscript equations and range of validity

\begin{tabular}{|c|c|c|}
\hline \multicolumn{3}{|l|}{ Specific gravity } \\
\hline$S u b_{\rho}=\{$ & $\begin{array}{l}3 \\
100 e^{1-\frac{\rho-0.9157}{0.075}-e \frac{\rho-0.9157}{0.075}}\end{array}$ & $\begin{array}{r}\rho<0.7770 \\
0.7770 \leq \rho \leq 1.3529 \\
\rho>1.3529\end{array}$ \\
\hline \multicolumn{3}{|l|}{ Melting point } \\
\hline$S u b_{M P}=\{$ & $\begin{array}{l}3 \\
-0.0942^{\circ} C^{-1} M P^{2}+7.0732^{\circ} C^{-1} M P-32.757 \\
3\end{array}$ & $\begin{array}{r}M P<5.5^{\circ} \mathrm{C} \\
5.5^{\circ} \mathrm{C} \leq M P \leq 69.5^{\circ} \mathrm{C} \\
M P>69.5^{\circ} \mathrm{C}\end{array}$ \\
\hline \multicolumn{3}{|l|}{ Solidification point } \\
\hline$S u b_{S P}=\{$ & $\begin{array}{l}3 \\
-0.4022^{\circ} C^{-2} s p^{2}+29.3593^{\circ} C^{-1} s p-473.7215 \\
3\end{array}$ & $\begin{array}{r}S P<21^{\circ} \mathrm{C} \\
21^{\circ} \mathrm{C} \leq S P \leq 52^{\circ} \mathrm{C} \\
S P>52^{\circ} \mathrm{C}\end{array}$ \\
\hline \multicolumn{3}{|l|}{ Refractive Index } \\
\hline$S u b_{\eta}=\{$ & $\begin{array}{l}3 \\
-302269.69 \eta^{2}+881070.145 \eta-641889.00115 \\
3\end{array}$ & $\begin{aligned} \eta & <1.4394 \\
1.4394 \leq \eta & \leq 1.4752 \\
\eta & >1.4752\end{aligned}$ \\
\hline \multicolumn{3}{|l|}{ Saponification Index } \\
\hline$S u b_{S a p}=\{$ & $\begin{array}{c}3 \\
100 e^{1-\frac{\operatorname{Sap}-207.3}{50}-e \frac{\operatorname{Sap}-207.3}{50}} \\
3\end{array}$ & $\begin{array}{r}\text { Sap }<114.8 m g \\
114.8 m g \leq \text { Sap } \leq 1.3529 \\
\text { Sap }>432.1 \mathrm{mg}\end{array}$ \\
\hline \multicolumn{3}{|l|}{ Iodine Index } \\
\hline$S u b_{I}=\{$ & $\begin{array}{l}3 \\
-0.0419 I^{2}+4.0332 I 2.9455 \\
3\end{array}$ & $\begin{array}{r}I<0.1 \\
0.1 \leq I \leq 96.1 \\
I>96.1\end{array}$ \\
\hline \multicolumn{3}{|l|}{ Unsaponifiable materials } \\
\hline $\operatorname{Sub}_{U \text { Sap }}=$ & $\left\{\begin{array}{l}-0.0405 m g^{-2} \text { USap }-0.8711 \mathrm{mg}^{-1} \text { USap }+100 \\
3\end{array}\right.$ & $\begin{array}{r}0 \leq \text { USap } \leq 39 \mathrm{mg} \\
\quad \text { USap }>39 \mathrm{mg}\end{array}$ \\
\hline \multicolumn{3}{|l|}{ Acidity Index } \\
\hline$S u b_{A}=\{$ & $\begin{array}{l}-0.0992 A^{2}+6.9807 A+100 \\
3\end{array}$ & $\begin{aligned} 0 \leq & A \\
& \leq 19.1 \\
A & >19.1\end{aligned}$ \\
\hline \multicolumn{3}{|l|}{ Humidity } \\
\hline $\mathrm{Sub}_{H}=$ & $\begin{array}{l}-0.0271 H^{2}+0.0393 H+100 \\
3\end{array}$ & $\begin{array}{r}0 \leq H \leq 60 \\
H>60\end{array}$ \\
\hline \multicolumn{3}{|l|}{ Suspended solids } \\
\hline$S u b_{S S}=\{$ & $\begin{array}{l}-0.0271 S s^{2}+0.0393 S s+100 \\
3\end{array}$ & $\begin{array}{r}0 \leq s s \leq 60 \\
s s>60\end{array}$ \\
\hline \multicolumn{3}{|l|}{ Peroxide } \\
\hline$S u b_{P}=\{$ & $\begin{array}{l}-2.9 m e q^{-1} P+100 \\
3\end{array}$ & $\begin{array}{r}0 \leq P \leq 34.5 \mathrm{meq} \\
P>34.5 \mathrm{meq}\end{array}$ \\
\hline
\end{tabular}


TABLE 4. (Continued)

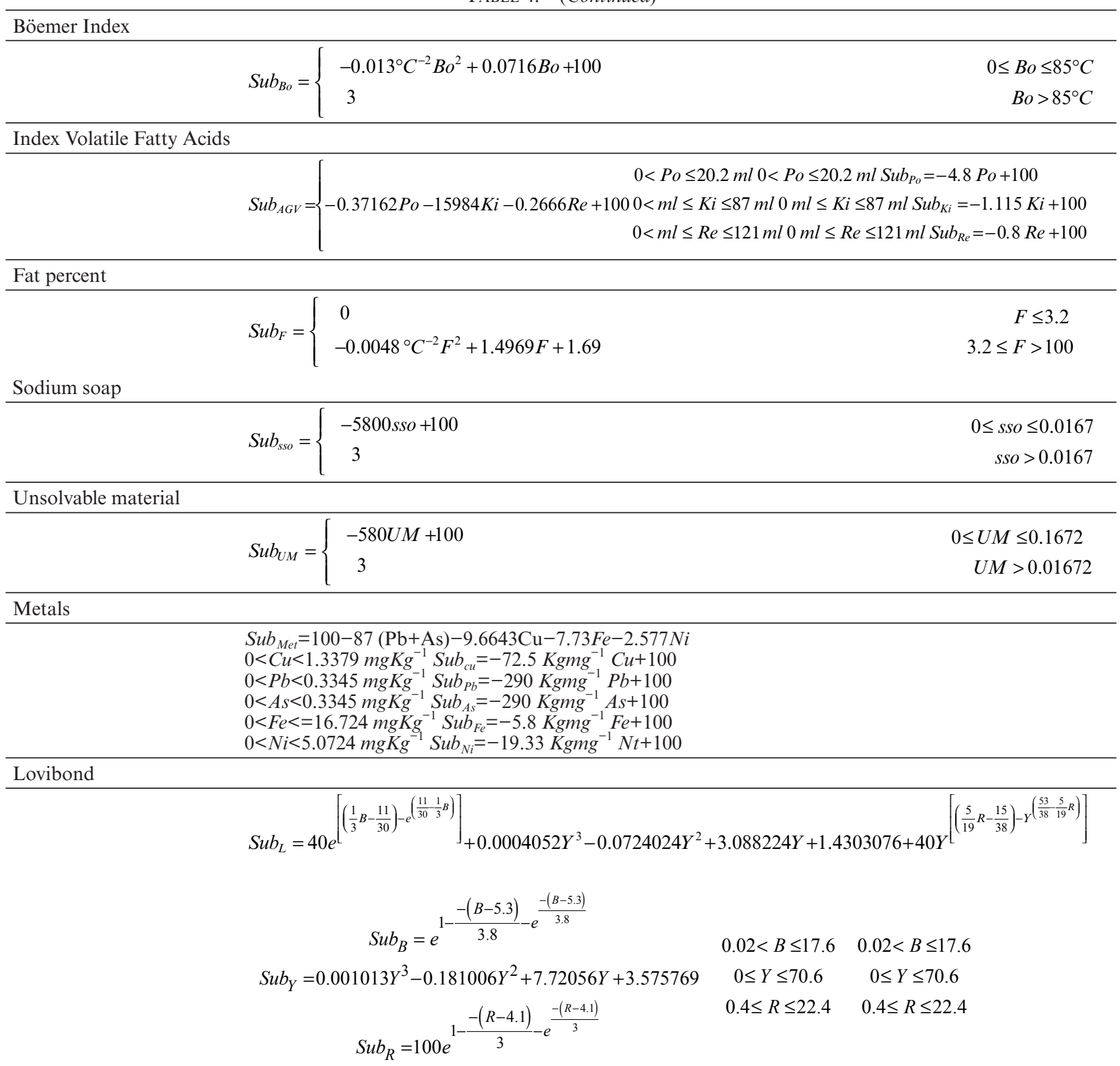

Unsaturated/Saturated

$$
\begin{aligned}
& \begin{aligned}
\frac{\text { Insat }}{\text { Sat }} & <0.0001 \\
0.0001 \leq \frac{\text { Insat }}{\text { Sat }} & \leq 6.3240 \\
\frac{\text { Insat }}{\text { Sat }} & >6.3240
\end{aligned} \\
& \text { Sub } \frac{\text { Insat }}{\text { Sat }}=\left\{\begin{array}{c}
9.3312 \ln \frac{\text { Insat }}{\text { Sat }}+8279 \\
100
\end{array}\right.
\end{aligned}
$$

\section{CONCLUSIONS}

The proposed FQI achieves the grouping of all standard quality parameters in a single weighed numerical value, making it a viable option for the interpretation of the values of the physicochemical and organoleptic variables inherent in the quality of fats, as the different variables are combined to result in a value that can be easily interpreted by the general population. 


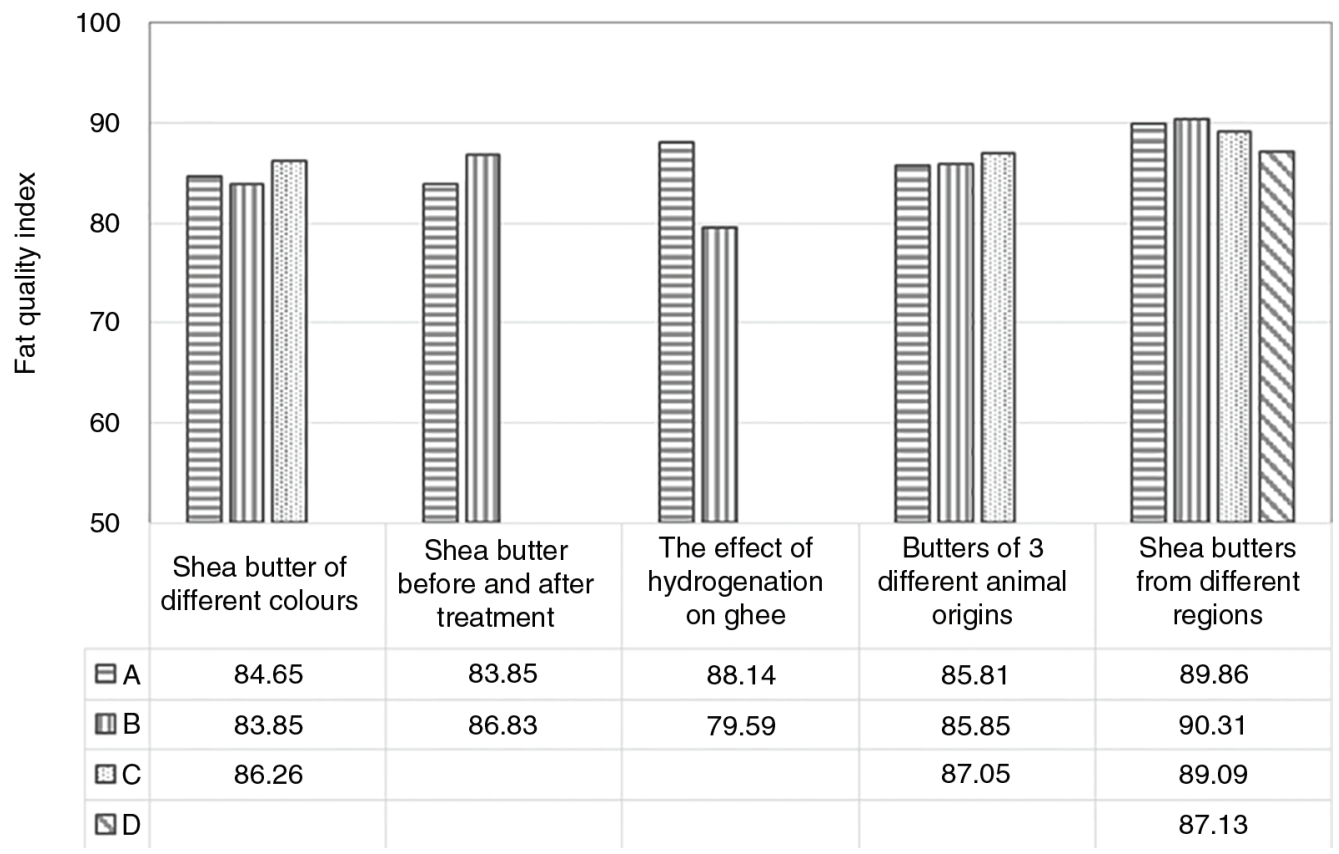

FIGURE 20. Employment of the fat Quality Index on five experimental works, demonstrating its usefulness in interpreting experimental fat samples.

Each quality parameter has a different behavior regarding its statistical distribution, based on the results obtained in accordance with the regulations; therefore, different types of mathematical models were implemented to adequately describe these behaviors, obtaining a sub-index for each.

Finally, the applications of the fat quality index shown in this paper demonstrate its usefulness for the discussion of results and the elucidation of conclusions with appropriate grouping and interpretation of all parameters that make up the quality of the fat under study.

\section{ACKNOWLEDGEMENT}

The authors thank the Academic groups UVERCA-226: "Estudio integral de ingenieríaaplicada" and UVER-CA-160: "Química de compuestos con posible actividad biológica", Faculty of Chemistry of the University of Veracruz Orizaba, for providing facilities for the development of this work. JACM acknowledges support from the program "Cátedras Conacyt".

\section{REFERENCES}

Código Alimentario Argentino, 2012. Normas argentinas Artículo 541 -(Res 2012, 19.10.84) "Alimentos grasos y aceites comestibles", Buenos Aires. Argentina.

Comisión Venezolana de Normas Industriales, 1994. COVENIN 120:1994 "Mantequilla", Fondonorma. Caracas.

Comisión Venezolana de Normas Industriales, 1995. COVENIN 704, 705, 706, 708, "Determinaciones de Aceites y Grasas Vegetales", Caracas. Venezuela.
Comisión Venezolana de Normas Industriales, 1996. COVENIN 1727 "Aceites y Grasas Vegetales, Determinacion de punto de fusión metodo de Wiley", Caracas. Venezuela.

Comisión Venezolana de Normas Industriales, 1997. COVENIN 1726 "Aceites y Grasas Vegetales", Caracas.Venezuela.

Comisión Venezolana de Normas Industriales, 1997. COVENIN 508 "Norma General de Aeeites Comestibles", Caracas. Venezuela.

Comisión Venezolana de Normas Industriales, 1998. COVENIN 3369:1998 "Alimentos para animales, grasa animal", Caracas. Venezuela.

Comisión Venezolana de Normas Industriales, 2000. COVENIN 2192:2000 "Margarina", Caracas. Venezuela.

Comisión Venezolana de Normas Industriales, 2001. COVENIN 325 "Determinación de Acidez en aceites Vegetales", Caracas. Venezuela.

Comisión Venezolana de Normas Industriales, 2001. COVENIN 70:2001 "Margarina", Caracas. Venezuela

Dhurvey Y, Kawtikwar P, Sakarkar D. 2012. Evaluation of physicochemical propieties of cow Ghee before and after hydrogenation. Int. J. Chem. Tech. Res. 4, 185-189.

Diario Oficial de la Federación, 1982. NMX-F-010-1982 "Alimentos para humanos. Mantequilla de leche o crema", Cd. de México.

Diario Oficial de la Federación, 1999. NMX-F-110-1999 "Manteca de Cerdo. denominación, especificaciones y métodos de prueba", Cd. de México. México.

Diario Oficial de la Federación, 2005. NMX-F-373-SCFI-2005 "Alimentos-Manteca vegetal y grasa comestible", Cd. de México. México.

Diario Oficial de la Federación, 2007. NMX-F-016 SCFI-2007 "Alimentos-Margarina para mesa", Cd de México. México.

Diario Oficial de la Federación, 2007. NMX-F-165-SCFI-2007 "Alimentos-Margarina Para Uso Industrial", Cd. de México. México.

Flores-Jacinto P, Meléndez-Estrada J, Amezcua-Allieri MA. 2013. Propuesta de índice de calidad de agua residual utilizando un modelo aritmético ponderado. Interciencia, $\mathbf{3 8}$, $145-149$.

Hee-Yong S, Si-Hong L, Jae-Hun R, Seong-Youl B. 2012. Biodiesel production from waste lard using supercritical methanol. J. Supercrit. Fluids. 61, 134-138. 
Instituto Colombiano de Normas Técnicas y Certificación, 2013. NTC 198 "grasas y aceites comestibles vegetales y animales. Manteca (aceite sólido)", Bogotá. ICONTEC.

Instituto Ecuatoriano de Normalización, 2011. NTE INEN 161:2011 "Mantequilla, Requisitos", Quito. Ecuador.

Instituto Ecuatoriano de Normalización, 2012. NTE INEN 1313 "Mantecas comestibles. Requisitos", Quito. Ecuador.

Instituto Nacional de Normalización , 1979. NCh1654. Of1979 "Mantequilla-Determinación de agua, sólidos no grasos y grasos", Santiago de Chile. INN.

Instituto Nacional de Normalización, 1958. NCh114.Of1958 "Mantecas y grasas animales comestibles", Santiago de Chile. INN.

Instituto Nacional de Normalización, 1958. NCh116.Of1958 "Mantecas y grasas vegetales comestibles", Santiago de Chile. INN.

Instituto Nacional de Normalización, 1966. NCh118.Of1966 Grasas y mantecas compuestas comestibles, Santiago de Chile. INN

Instituto Nacional de Normalización, 1969. NCh117. Of1969 Mantecas hidrogenadas comestibles-Especificaciones generales, Santiago de Chile. INN.

Instituto Nacional de Normalización, 1980. NCh1606/1. n1980 Cuerpos grasos de origen animal y vegetal-Parte 1: Preparación de ésteres metílicos de ácidos grasos, Santiago de Chile. INN.

Instituto Nacional de Normalización, 1981. NCh95. Of1981 Cuerpos grasos de origen animal y vegetal-Método para determinar la acidez libre, índice de acidez y acidez, Santiago de Chile. INN.

Integración, C.d.M.d., 2007. RTCA 67.04.40.07 "Alimentos y bebidas procesados. Grasas y aceites. Especificaciones", NA: Reglamento Tecnico Centro Americano.

Kulkarni MG, Dalahi AK. 2006. Waste Cooking Oil-An Economical Source For Biodiesel: A Review. Indus. Eng. Chem. Res. 45, 2901-2913. http://dx.doi.org/10.1021/ ie0510526.

Mercado Comun del Sur, 1993. MERCOSUR/GMCIRES. $N^{\circ}$ $70 / 93$ "Identidad y calidad de la manteca", Montevideo. Republica Oriental del Uruguay.
Okullo JBL, Omujal F, Agea JG, Vuzi PC, Namutebi A, Okello JBA, Nyanzi SA. 2010. Physico-chemical chraracteristic of shea butter (Vitellaria paradoxa C.F. Gaertn) oil from the shea districs of Uganda. African J. Food Agric. 10, 2070-2081.

Organización de las Naciones Unidas para la alimentacion y agricultura, 1981. CODEX STAN 19-1981 "Norma del CODEX para grasas y aceites comestibles", Roma: International Food Standars.

Organización de las Naciones Unidas para la alimentacion y agricultura, 1981. CODEX-STAN-086-1981, Roma: International Food Standars.

Organización de las Naciones Unidas para la alimentacion y agricultura, 1989. CODEX STAN 32 "Norma del CODEX para la margarina", Roma: International Food Standars.

Organización de las Naciones Unidas para la alimentacion y agricultura, 1999 CODEX STAN 211"CODEX STANDARD FOR NAMED ANIMAL FATS", Roma: International Food Standars.

Rose-Monde M, Niamke S, Diopoh J. 2007. Physicochemical and microbiological Characteristics of optimized and traditional Shea butter from côte d'lvoire. African J. Biochem. Res. 1, 41-47.

Sağdiç O, Donmezb M, Demirci, M. 2004. Comparison of characteristics and fatty acid profilesof traditional Turkish yayik butters produced from goats', ewes' or cows' milk. Food Cont. 15, 485-490. http://dx.doi.org/10.1016/j.foodcont. 2003.07.003.

Samboni-Ruiz NE, Carbajal-Escobar Y, Escobar JC. 2007. Revisión de parámetros fisicoquímicos como indicadores de calidad y contaminacion del agua. Ingenieria Investigación, 27, 172-181.

Valenzuela A, Yáñez CG, Golusda C, 2010. ¿Mantequilla o Margarina? Diez años después. Rev. Chilena Nutr. 37, 505-513.http://dx.doi.org/10.4067/S0717-75182010000400012.

Van Helmond C, Breukel R. 1997. Physico-Chemical water quality indices. En: Procedings of an International Works on Information Strategies. Nunspeet: s.n., pp. 475-479. 